A Debreceni Egyetem Általános Orvostudományi Kar Traumatológiai és Kézsebészeti Tanszék ${ }^{1}$, Kenézy Gyula Kórház és Rendelőintézet Baleseti Sebészeti és Kézsebészeti Osztály², Debrecen, közleménye

\title{
Betegutak és sürgősségi osztály tervezés
}

\author{
DR. FRENDL ISTVÁN¹, DR. BALÁZS JÓZSEF², DR. URBÁN FERENC',
}

\author{
DR. TURCHÁNYI BÉLA ${ }^{1}$
}

\section{ÖSSZEFOGLALÁS}

Magyarországon a sürgősségi ellátás javítására, az utóbbi húsz évben számos fejlesztés valósult meg, azonban a sürgősségi osztályok belső térkialakítása nem egységes elvek szerint történik, pedig a belső terek kialakítása és az infrastruktúra alapvetően meghatározza a betegutak szervezését és az ellátás minőségét. A közlemény a fejlett egészségügyi rendszerű országok - a magyarországi SBO1 szintnek megfelelő - sürgősségi ellátó helyeinek belső térkialakítási és szervezési alapelveit foglalja össze.

\section{Kulcsszavak: $\quad$ Betegutak; Kórháztervezés; Sürgősségi betegellátás; Sürgősségi Osztály;}

I. Frendl, J. Balázs, F. Urbán, B. Turchányi: Emergency medical concepts and emergency department design

Many improvements have been made in the emergency medical services system over the past twenty years in Hungary. Unfortunately the basic principles of the interior design of emergency departments in the country are not uniform, even though the layout of infrastructure and interior design can basically determine the management of patient flow and the quality of patient care. The present article summarizes the organizational principles and interior design of emergency departments in developed countries, according to the appropriate level of the SBO1 in Hungary.

Keywords: $\quad$ Emergency medical services-Methods/Standards;

Emergency medicine - Methods/Standards;

Hospital design and construction;

Patient admission - Standards; Patient transfer - Standards; 


\section{BEVEZETÉS}

Magyarországon a sürgősségi ellátás javítására az utóbbi húsz évben számos fejlesztés valósult meg $(3,6)$. A sürgősségi osztályok belső térkialakítása azonban nem egységes elvek szerint történik, pedig a belső terek kialakítása és az infrastruktúra alapvetően meghatározza a betegutak szervezését és az ellátás minőségét. Számos kórház és klinika még mindig sok telephelyü, vagy pavilonrendszerü, ezért a különböző szakmák sürgősségi ellátó helyei szétaprózottak. A magyar orvostársadalom sem egységes abban, hogy angolszász rendszerű egységes sürgősségi osztályokat, vagy német-francia rendszerű szakmánként külön sürgősségi ellátó helyeket, ambulanciákat akar-e.

Világszerte, így a német-francia sürgősségi modellü egészségügyi rendszerekben is, elterjedőben van az angolszász típusú egységes sürgősségi osztályok kialakítása. Ez az egészségügyi „modernizáció és globalizáció”, úgy látszik Magyarországon is elkerülhetetlen. Hazánkban a progresszivitásnak megfelelően sürgősségi fogadóhely (SF), sürgősségi betegellátó osztály 2 (SBO2), sürgősségi betegellátó osztály 1 (SBO1) és bizonyos speciális szakmákban sürgősségi centrum (SC) minősítésű ellátó helyek vannak. A megyei kórházak és az egyetemi központok általában SBO1 minősítésű sürgősségi betegellátó osztállyal rendelkeznek.

Az alábbiakban a fejlett egészségügyi rendszerű országok azon sürgősségi ellátó helyeinek belső térkialakítási és szervezési alapelveit szeretnénk összefoglalni, amelyek a magyarországi SBO1 szintnek felelnek meg.

\section{A sürgősségi ellátás prehospitalis szakasza}

A sürgősségi ellátás prehospitalis szakaszában a német-francia mentési filozófia a „maradj és stabilizáld” (angolul: stay and stabilize), míg az angolszász mentési filozófia, a „lapátold föl és szaladj” (angolul: scoop and run) alapelven nyugszik (5). A két mentési filozófia abban is különbözik, hogy a németfrancia rendszerű magasabb szintű mentőkocsikban a legsúlyosabb betegekhez és sérültekhez orvos, míg az angolszász rendszerü magasabb szintű mentőkocsikban speciálisan képzett mentőtiszt (angolul: Emergency Medical Technician - Paramedic $=$ EMT $-P$ ) érkezik a riasztás helyszínére (17).

A magyar mentési filozófia a németfrancia alapelveket alkalmazza. Az Országos Mentőszolgálat rohamkocsin és helikopteres mentőn dolgozó orvosai jelentős prehospitalis triage-t valósítanak meg.

\section{A sürgösségi ellátás hospitalis szakasza}

A német-francia modell szerint minden szakmának önálló sürgősségi ellátó helye, ambulanciája van $(2,16)$. Német nyelvterületen a sérülteket baleseti kórházakban és baleseti klinikákon dolgozó baleseti sebész látja el.

$A z$ angolszász modell szerint sürgősségi osztályokon (Emergency Department) látják el a betegeket és a sérülteket $(1,14)$. A sürgősségi osztályon belül acut/emergent (sürgős) és urgent (kevésbé sürgős), vagy major care (súlyosabb) és minor care (kevésbé súlyos) részre osztják az osztályt, de a sebészeti és a belgyógyászati betegeket nem különítik el. Ez a legelterjedtebb modell a világban. A sürgősségi orvos (emergency physician) elvégzi a diagnosztikát és alapszinten nagyon sok mindent ellát, azonban gyakran kér konzíliumot specialistáktól. A sürgősségi orvostan (emergency medicine) önálló diszciplína és szakvizsga. Az ortopéd sebészek látják el a mozgásszervi sérüléseket (orthopaedic trauma). Az ortopéd sebészt csak akkor hívják, ha el kell dönteni, hogy kell-e operálni, és/vagy osztályra felvenni a beteget. A trauma sebész (trauma surgeon) olyan általános sebész, aki tovább specializálódva mellkasi, hasi és nagyér-sérülések ellátásával foglalkozik.

Az izraeli modell szerint a sürgősségi osztályokon belül Sebészeti (Surgery) és Belgyógyászati (Internal Medicine) rész van.

\section{ANYAG ÉS MÓDSZER MODELL BEMUTATÁSOK}

\section{A német modell}

A német modellre jó példa a bécsi Lorenz Böhler Baleseti Kórház (Unfallkrankenhaus Lorenz Böhler = UKH Böhler), amelynek 
ambulanciái évente 60 ezer sérültet látnak el (1. ábra). A fölszinten lévő baleseti ambulanciának külön járóbeteg bejárata, külön mentő bejárata és külön shocktalanító bejárata van, és az ellátás során is igyekeznek elkülöníteni ezen különböző súlyosságú betegcsoportokat. A sérültellátás során érvényesül az egyirányú betegutak elv. Külön útvonalon halad a friss, és külön az utókezelős betegek ellátása. Ezt külön színkódokkal - színcsíkokkal - is feltüntetik a betegutak jelzésére. A két beteganyag a várókban sem keveredik. A friss sérültek ellátásán belül külön helyen folyik a járóbetegek, és külön helyen a fekvőbetegek ellátása. Az épület földszinti központi részén helyezkedik el a röntgendiagnosztika, amely egyik oldalon a friss sérültellátást, a másik oldalon a kontrollos betegellátást szolgálja ki. Közvetlenül a shocktalanító mellett található a CT.

$\mathrm{Az}$ egy légtérben lévő sebellátó - gipszelő (3-3 ággyal) - egyik oldalon a friss sérültellátást, a másik oldalon az utókezelős betegellátást látja el. A sebellátó - gipszelőben az ágyakat paravánfal választja el egymástól, a plafonon lévő sínen mozgatható digitális röntgenkészülék húzható az ágyak fölé, így a betegeket nem kell repozíció után ismét a röntgenbe átvinni, illetve idegentest keresése esetén helyben van a röntgen. Mindez a betegek minél kevesebb mozgatását segíti elő.

Alapelv, hogy lehetőleg az ellátó személyzet mozogjon, és ne a beteg. A mégis szükségessé váló betegmozgatást hátsó munkafolyosókon oldják meg, így is elkülönítve egymástól a különböző súlyosságú betegcsoportokat (I. táblázat, 2-3. ábrák).

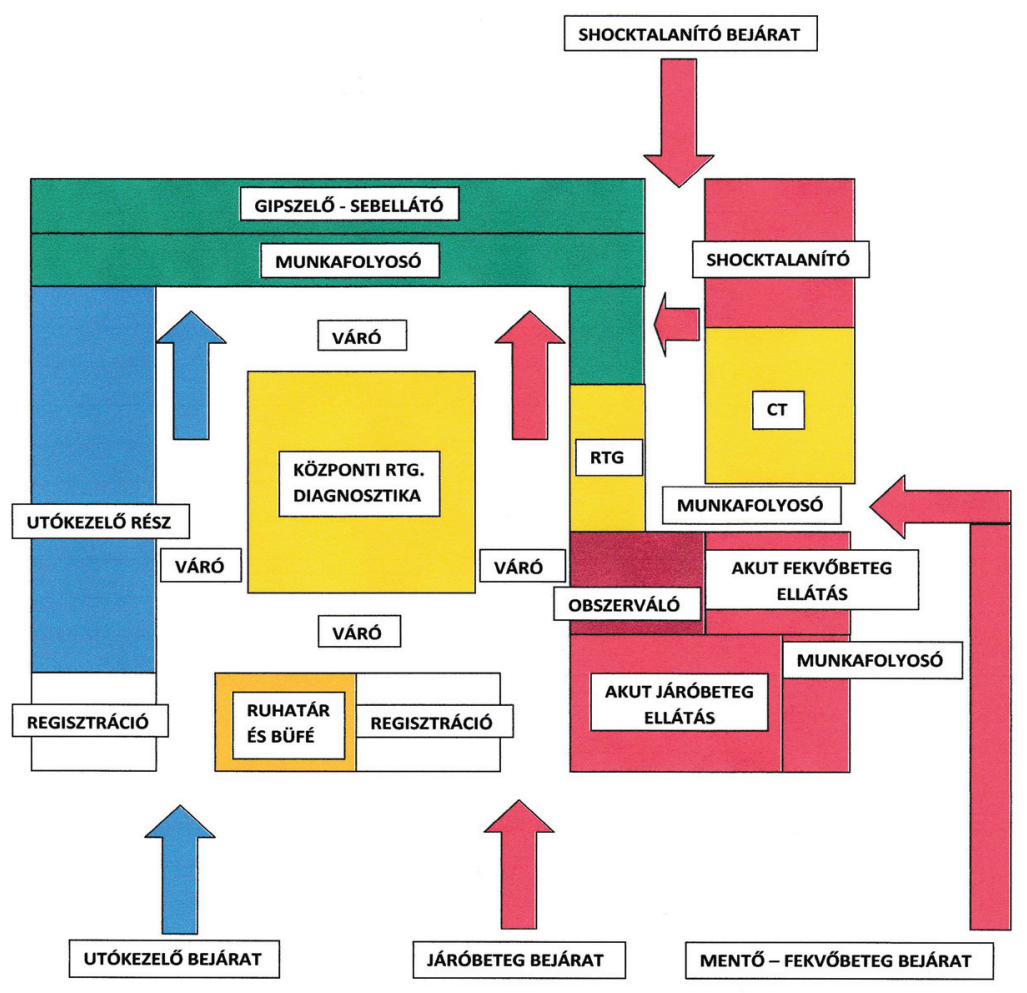

1. ábra A Lorenz Böhler Baleseti Kórház, Bécs, Ausztria földszinti sematikus alaprajza A központi részen középen: diagnosztika - röntgen

Felül: sebellátó - gipszelö (3-3 ágy, a plafonon sínes mobil digitális röntgen)

A központi részen elhelyezkedő diagnosztika - röntgen, és az ábrán felül elhelyezkedő egy légtérben lévő egységes sebellátó - gipszelö, kiszolgálja mind az akut (jobb oldal), mind az utókezelös (bal oldal) sérültellátást. 


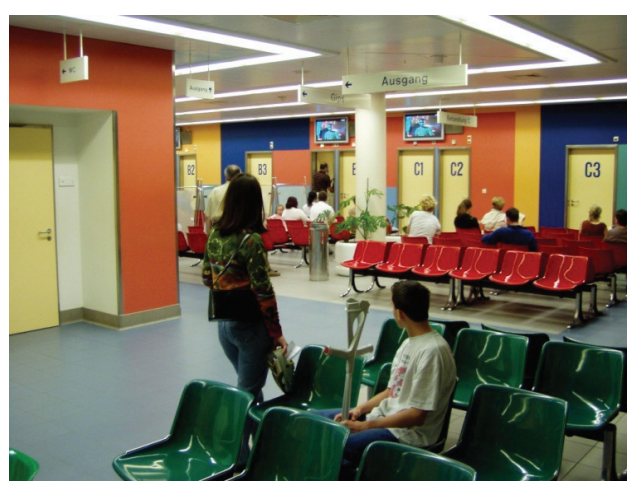

2. ábra Tágas várók a Böhler Baleseti Kórházban, Bécs, Ausztria (saját fotó)

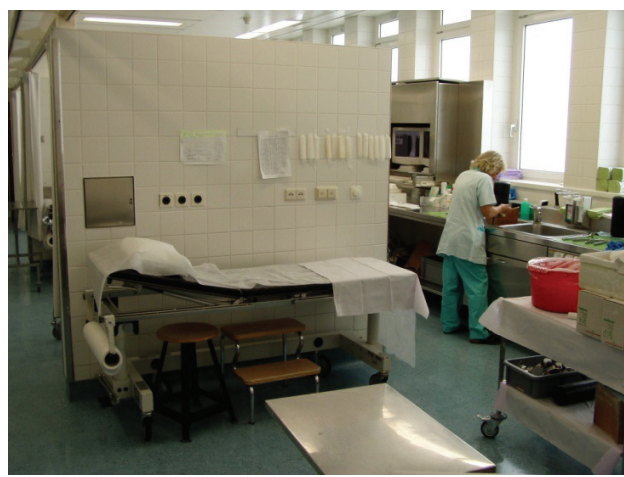

3. ábra Egylégterü sebellátó - gipszelö

A képen csak sejthetö a mennyezeten futó sín, mely mobil röntgen készülék mozgatására szolgál (saját fotó)

\section{I. táblázat UKH Böhler alapelvek}

A fölszinten lévő baleseti ambulanciának külön járóbeteg bejárata, külön mentő bejárata és külön sokktalanító bejárata van.

A beteg érkezésekor az első lépés a beteg regisztráció - bejelentkezés, adatfelvétel (Anmeldung).

Ezután történik a beteg első vizsgálata - osztályozás (Erstversorgung).

A járóbetegek, mentős - fekvőbetegek és a sokktalanítóba érkező polytraumatizáltak ellátását térben is szétválasztják.

\section{Az akut és az utókezelős betegellátást térben is elkülönítik.}

A hátsó munkafolyosó elv szerint a mentővel érkezett fekvőbetegek és a súlyosabb sérültek az első vizsgálat után egy hátsó munkafolyosón jutnak el a képalkotó diagnosztikához, és ha szükséges az egy légterű sebellátó - gipszelőbe, vagy a mútőbe. A fekvőbetegeket és a súlyosabb sérülteket elkülönítik a járóbetegektől és a gyermekektől. Ugyanakkor az orvosok a hátsó munkafolyosón átmenve konzultálni tudnak egymással.

Általában napközben két járóbeteg ambulanciát és egy mentős ambulanciát folyamatosan múködtetnek.

A kórház négy baleseti osztálya rotációs munkarendben dolgozik (sürgősségi - ügyeleti nap, pihenőnap, utókezelős nap, elektív mútétes nap). A rotációs munkarendet azért vezették be, mert a folyamatos készenlét felőrli, kiégeti az orvosokat. A forgó rendszer kiszámítható ritmust ad a munkának.

Sürgősségi - ügyeleti napon 12 órát nem meghaladó múszakos munkarendben dolgoznak

(az EU direktívának megfelelően), a többi munkanapon 8 órás munkarendben dolgoznak.

Betegátadás - átvétel van a nappalos és az éjszakás, valamint az éjszakás és a nappalos teamek között. 


\section{Az angolszász modell}

\section{Emergency Medical Services (EMS) - USA}

Az Amerikai Egyesült Államok Kongresszusa 1973-ban hozott törvényt a Sürgősségi Egészségügyi Szolgálatok Rendszere (Emergency Medical Services System = EMSS) kialakítására (EMS Systems Act of 1973, Public Low 93-154). Az EMS System egy integrált rendszer, az USA valamennyi államában a helyi egészségügyi minisztériumon belül egy iroda múködik a rendszer összehangolására. A rendszer része a mentőszolgálat (Ambulance Service), a tǔzoltóság (Fire Department $=$ FD), a rendőrség (Police Department $=P D$ ) és a kórházak sürgősségi osztályai (Emergency Department - vagy a közbeszédben - Emergency Room = ER). Katasztrófa helyzetben (disaster situation) a polgári védelem (Civil Defense), a hadsereg (Army) és a vöröskereszt (Red Cross) egységei is csatlakoznak a rendszerhez.

Betegség vagy baleset esetén a lakosság az USA-ban az egységes ingyenes 911 segélykérő számot hívja. A központban a diszpécser monitora előtt megjelenik a hívó fél telefonszáma (enhanced 911), így azonosítani tudja a hívó fél címét, ha a beteg állapota miatt a vonal megszakad. Ezen példa alapján hozták létre Magyarországon is az egységes segélykérő telefonszámot. A helyszínre a rendőrségi autó és a mentőautó egyszerre érkezik (Police) EMSS). Sok helyen a mentőautó egyben túzoltóautó is. A mentőautó személyzete speciálisan képzett mentőtisztekből (Emergency Medical Technicians = EMT) áll. Az EMT-knek három szintje van. EMT-A (basic), EMT-I (Intermediate), EMT-P (Paramedic). Az EMT-P a legmagasabb szint. Mindhárom szint képzési programhoz és vizsgához kötött.

\section{Progresszivitási szintek}

$\mathrm{Az}$ American Medical Association (AMA) a kórházi centrumokat a speciális kritikus sürgősségi állapotok ellátásának szempontjából az alábbi centrumokra osztályozza (15):

$\begin{array}{ll}\text { akut belgyógyászati } & \text { (acut medical) } \\ \text { baleseti } & \text { (trauma) } \\ \text { gerincvelő } & \text { (spinal cord) } \\ \text { viselkedési/pszichiátriai (behavioral) } \\ \text { égési } & \text { (burns) }\end{array}$

kardiális (cardiac)

újszülött (neonatal/perinatal)

mérgezés és kábitószer (poisoning and drug)

Mindegyik típusú centrumból három fokozat van (I-II-III). A legmagasabb szint az I. fokozat (például level one trauma center).

Első fokozat (level one center): Teljes spektrumú trauma központtal rendelkezik és minden szakterület képviseltetve van a kórházban.

Második fokozat (level two center): Hasonló az I. fokozathoz, de nincs oktatás és kutatás, és a legsúlyosabb sérülteket vagy betegeket esetenként az I. fokozatú intézetbe átszállítják az állapot stabilizálása után.

Harmadik fokozat (level three center): Ez a fokozat nem rendelkezik az I. és II. fokozat lehetőségeivel, de egy adott területen a legmagasabb elérhető ellátási szint lehet. Az életmentő beavatkozásokat és a beteg állapotának stabilizálását elvégzik, és utána általában a beteget az I. és II. fokozatú központba átszállítják.

A Kórházak Közös Akkreditációs Bizottsága (Joint Commision on Accreditation of Hospitals $=J C A H)$ az ER-eket négy szintre osztja:

\section{1.) level I ER: (legmagasabb szint):}

24 órán át legalább egy sürgősségi szakorvos (emergency medical physicians) dolgozik az osztályon. Munkáját más szakterületek szakorvosai és nem szakorvosok segítik forgó (rotation) rendszerben. A kórházon belül elérhető szakorvos, vagy felsőbb éves szakorvosképzésben résztvevő orvos (senior resident) az alábbi szakterületekről:

- belgyógyász

- általános sebész

- ortopéd/trauma sebész

- szülész-nőgyógyász

- gyerekgyógyász

- anaesthesiológus

Más konzultáns specialista 30 percen belül behívható.

\section{2.) level II ER}

24 órán át legalább egy sürgősségi szakorvos dolgozik az osztályon, szakorvos vagy felsőbb éves szakorvosképzésben résztvevő orvos (senior resident) behívható, más specialista 30 percen belül beér.

\section{3.) level III ER}

24 órán át behívható egy sürgősségi szakorvos, aki 30 percen belül beér. 


\section{4.) level IV ER}

Szükség esetén életmentő beavatkozásokat képesek végezni, és a beteg állapotának stabilizálása után átszállítják a beteget magasabb szintű ER-be.

A városokban általában I. és II. szintű ER-ek vannak.

\section{Angolszász rendszerü sürgősségi osztály (Emergency Department) kialakitása}

ED olyan kórházban létesíthető, ahol lehetőleg minden szakterület képviselve van, és lehetőleg minden beteget véglegesen el tudnak látni. $A$ beteg átszállítását más kórházba el kell kerülni. Az USA Emergency Medical Services rendszere eleve igyekszik a beteget a végleges ellátás helyére szállítani.

Fontos az ED könnyű elérhetősége más osztályokhoz, főleg a képalkotó diagnosztikához, a mútőkhöz, az intenzív osztályhoz, a laboratóriumhoz és a vér bankhoz való közelsége. A shocktalanító mellett - amely teljes felszereltségű mútő is egyben - található a CT. Az ED sok osztállyal működik együtt, így fontos a jó személyes és szakmai kapcsolat a kórház osztályaival. Az ED a földszinten helyezkedik el. Az ED-ket a legtöbb kórházban a legújabb épületrészekben alakítják ki, hogy megfeleljenek a belső és külső feltételeknek. Az ED bejárata gyalog és jármúvel jól megközelíthető, jól felismerhetően feliratozott, jól kivilágított, széltől, esőtől tetőrésszel védettnek kell legyen. A bejárat mellett tárolónak kell lennie a fekvő- és ülőkocsiknak.

Mindig kell lenni szabad parkolóhelynek a bejárat előtt, erről a kórház vezetésének és a biztonságiaknak gondoskodnia kell, mivel gyakran a kritikus állapotban lévő beteget magán gépkocsival hozzák be a lakosok. Közvetlenül a bejárat mellett kell lennie a biztonsági szolgálat őrhelyének. Ezt (és más helyeken is) érdemes törhetetlen ablakokkal ellátni.

Sok beteg csak az ED-ben jár, nem kerül felvételre osztályra, az ED-ben tapasztaltak alapján ítéli meg a közösség a kórház szolgáltatásait, így az ED működése meghatározó a kórházról kialakult kép szempontjából. Ezért a kórházi managementnek az ED-re a többi osztályokénál nagyobb figyelmet kell fordítania. Az ED takarítását 24 órán át biztosítani kell.

\section{Feliratozás, átláthatóság}

Egy korszerű angolszász kórház előtt megállva a következő feliratok láthatóak:

Emergency (sűrgősségi ellátás), Outpatient (járóbeteg bejárat, szakrendelések és egynapos sebészet felé), Inpatient (bejárat a fekvőbeteg osztályok felé).

A sürgősségi osztályra érkező betegek a váróban (a betegtájékoztatókon kívül) három fontos feliratot látnak: Registration (regisztráció, adatfelvétel, beteg bejelentkezés), Triage (osztályozás), Security (biztonsági szolgálat). Igen fontos a sürgősségi osztályok bejárata mellett betegfürdető, betegfertőtlenítő helyiség (Decontamination room) kialakítása (II. táblázat).

\section{Betegutak, betegáramlás (patient flow)}

A sürgősségi osztály várójában a betegeket a regisztráció után a triage nurse (osztályozó nővér) fogadja, és az elkülönített triage vizsgálóban kikérdezi, megvizsgálja és súlyossági sorrendet felállítva osztályozza őket. Mindenkinek vérnyomást, pulzust és testhőmérsékletet mér, rákérdez az esetleges gyógyszerallergiára, betegségekre és aláiratja a vizsgálati beleegyező nyilatkozatot. Minden beteg múanyag vonalkódos karszalag betegazonosítót kap. A triage után a beteg bekerül az ellátó részbe (patient care area), és ezután már nem kerül vissza a váróba. Az ellátás alatt lévő és a váróban lévő betegek nem keverednek össze.

Bár a sürgősségi osztály külön járóbeteg és külön mentő bejárattal rendelkezik, a triage egységes, úgynevezett egykapus rendszerú. $A z$ ellátó térből beteg felügyelet nélkül nem tud elszökni, legvégső esetben a bejáratnál lévő biztonsági szolgálat az útját állja.

Újabb tendencia, hogy a triage-t nem triage nővér hanem triage orvos végzi. Több vizsgálat és közlemény szerint, ha triage orvos látja először a beteget, az az ellátás színvonalát jelentősen növeli.

Vizsgálat után eldől, hogy a beteg felvételre (admission) kerül-e kórházi osztályra (inpatient unit), vagy elbocsátásra kerül (discharge), és kontrollra a háziorvosához (private doctor, general practicioner) vagy az utókezelőbe (follow-up clinic) irányitják, illetve szüksége van-e a szociális szolgálat (social service) vagy a házi ápolási szolgálat (home care) igénybevételére (19). 


\section{II. táblázat Angolszász sürgösségi osztály alapelvek}

Az ED-nek a következő bejáratai vannak: külön járóbeteg bejárat (Walk-in entrance), külön mentő bejárat (Ambulance entrance) és külön shocktalanító bejárat (Trauma room entrance). A helikopter leszállóhely (Heliport) az épület mellett, vagy az épület tetején van.

A bejárat mellett van a biztonsági szolgálat (Security) őrhelye. A biztonsági szolgálat folyamatos jelenléte az egész sürgősségi osztály területén érzékelhető.

A bejárat mellett van a betegfürdető - betegfertőtlenítő helyiség (Decontamination room).

A beteg érkezésekor az első lépés a regisztráció - adatfelvétel.

Egységes triage - osztályozó rendszer van.

Valamennyi beteg műanyag vonalkódos karszalag betegazonosítót kap.

A váróban lévő és a triage után az ellátó részbe (patient care area) bekerült betegeket elkülönítik.

A sürgős (Acut vagy Emergent), kevésbé sürgős (Urgent), gyermek (Pediatric) és pszichiátriai (Behavioral) ellátást szétválasztják, ezekre külön részlegek vannak a sürgősségi osztályon belül.

A könnyebb esetek ellátására gyors részleg, gyors elkülönítő (Fast Track) részt hoznak létre.

Itt fotelszerű kényelmes dönthető háttámlájú székekben történetik a betegek ellátása és várakozása a diagnosztikai eredményekre.

Mellkasi fájdalmak esetén külön részlegen van a beteg (Chest Pain Unit).

Alkalmazzák a (Böhler Baleseti Kórháznál már említett) hátsó munkafolyosó elvet.

A munkafolyosókat mindig szabadon kell hagyni, ott betegek sem fekvőkocsiban sem ülőkocsiban nem tartózkodhatnak.

A sürgősségi osztályon nappalos és éjszakás 12 órás műszakos munkarendben dolgoznak.

Átadás - átvétel van a nappalos és az éjszakás teamek között.

Sokktalanító riasztás van, Sokktalanítóba érkező beteg esetén külön teamet mozgósítanak

(Trauma paging system - Code Trauma riasztás).

Az ATLS (Advenced Trauma Life Support) tanfolyam elvégzése minden ER-ben dolgozó orvos részére kötelező.

Emergency Medical Team (MET) vagy Core Team van a resuscitatiók végzésére és a kritikus állapotban lévő betegek ellátására.

A kórház osztályairól beteget az ED nem kap. Ez csak rendkívüli esetben fordulhat elő, segítségképpen, ha a kórház kapacitásai kimerülnek. Gyakran szükséges a beteg háziorvosával vagy specialista magánorvosával való telefonos konzultáció.

Világtendencia, hogy a sürgősségi osztályok forgalma évente 2-5\%-kal nő. Ennek több oka van: Az ED-kben a trauma, akut cardialis történések és agyvérzéses esetek adják a legnagyobb beteganyagot (trauma, heart attack, stroke). Az ED-kben az a tendencia, hogy a krónikus betegek, az idős betegek és a könnyebb esetek száma nő, és átfedések vannak a háziorvos (general practicioner, local doctor), a járóbeteg szakrendelések (outpatient department/clinic) és az ED beteganyagában (13). Ennek oka, hogy a nagyvárosokban sok a turista, az átutazó, a nem ott lakó bejáró dolgozó, és ezek nem a háziorvosukhoz, hanem az ED-hez fordulnak panaszaikkal (18).

Az ED könnyű elérhetősége miatt a közelben lakók egy része, és azok is, akiknek nem volt idejük munkaidőben felkeresni háziorvosukat és a járóbeteg szakrendeléseket, az ED-hez fordulnak. Az ED-k a lakosság egy része számára a szociális háló (safety net) utolsó láncszemei. Hogy milyen esetek keresik fel az ED-ket, függ a háziorvosok munkájától és a lakosság elvárásaitól is. Nincs választás, minden beteget el kell látni. Az ED-ben lehetőleg az ellátó orvosok mozognak és nem a beteg. A beteg minél kevesebb mozgatásával kell megoldani a diagnosztikus és terápiás teendőket. Ez az optimális betegutak (optimal patient flow) programok lényege. 
Az angolszász sürgősségi osztályok belső ellátó részének (patient care area) kialakítása és alaprajza alapvetöen az alábbi három koncepció valamelyikének a variációja:

A „bálterem” elrendezésű sürgősségi osztály előnye, hogy a központi nővérpultról körkörösen rálátnak a vizsgálókban lévő betegekre (4. ábra). A négyzet, téglalap vagy kör alaprajzú helyiség központi nővérpultjait 16 -18 vizsgáló veszi körül. Ettől több vizsgáló már áttekinthetetlenné teszi az ellátást. A „bálterem” kialakítású sürgősségi osztály a legelterjedtebb forma (20).

A lineáris kialakítású sürgősségi osztály előnye, hogy a központi nővérpultról egyik oldalon a kevésbé súlyos járóbetegekre, másik oldalon a súlyosabb mentővel érkezett fekvőbetegekre látnak rá (5. ábra). Az esetleges látogatók az alsó és felső szélső folyosón, a többi beteget nem zavarva és nem látva mehetnek be a vizsgálókba. A lineáris modell elterjedőben van, mert tömeges sérülések és megbetegedések esetén a legpraktikusabb elrendezés.

A matrix kialakítás nagy sürgősségi osztályok esetén alkalmazott elrendezés. Az előző két forma kombinációja, azok előnyeivel (6. ábra).

$\mathrm{Az}$ angolszász modellre jó példa a Springfield városában az USA Massachusetts államában lévő 2012-ben korszerű elveknek megfelelően felújított és kibővített sürgősségi osztály.

\section{Emergency Department, Baystate \\ Medical Center, Springfield, Massachusetts, USA}

A kórház Level one trauma center minősítéssel rendelkezik. A sűrgősségi osztály éves betegforgalma 110 ezer fő. A sürgősségi osztályon belül „bálterem” elrendezésű részlegek vannak (7-10. ábrák). A vizsgálók az új alapelveknek megfelelően multifunkcionálisak, minden szakterület részére alkalmas általános vizsgálók, nincs külön nőgyógyászati, fül-orrgégészeti, szemészeti stb. vizsgáló. A speciális kezelésekhez ( $p l$. sutura) külön set-eket használnak. A részlegeken belül a központi nővérpultról (central control area) rálátnak a vizsgálókban körkörösen lévő betegekre, és a beteg is rálát a nővérpultra. A vizsgálók már nem a régi rendszerű egymástól függönnyel elválasztott vizsgálók, hanem külön szobák, amelyeknek átlátszó törhetetlen üvegajtóik vannak. A vizsgálók hangszigeteltek (7-10, 12). A lakosság igénye a magánélet titoktartására (privacy), a bizalmas légkörre (confidentiality), és az emberi méltóság fenntartására (dignity) tette szükségessé az elkülönített vizsgálók kialakítását $(4,11)$. 


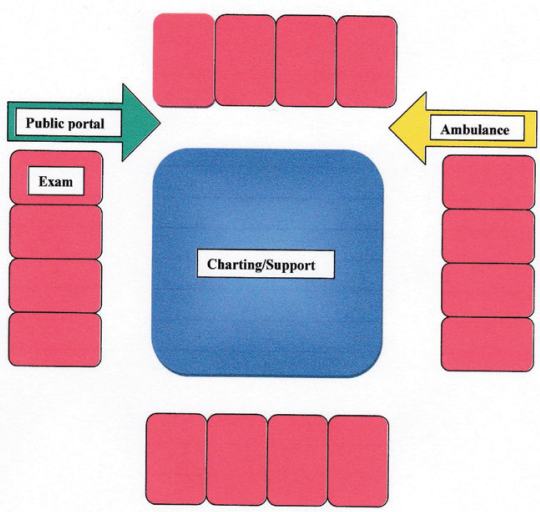

4. ábra „Ballroom” (magyarul: bálterem) kialakítású sürgősségi osztály

A 4-6. ábrák forrása: Zilm F.: Designing for emergencies. Health Facilities Management, Nov. 1. 2010.

http://www.hfmmagazine.com/display/HFM-news-article.dhtm/?dcrPath=/templatedata/HF_Common/NewsArticle/ data/HFM/Magazine/2010/Nov/1011HFM_FEA_AD

Piros szín (Exam) = Vizsgáló, kezelö

Kék szín (Charting/Support) = központi nővér pultok és komputerek, (felmérö/támogató rész)

Zöld nyíl (Public portal) = Nyilvános bejárat (járóbetegek)

Sárga nyíl (Ambulance) = Mentő bejárat
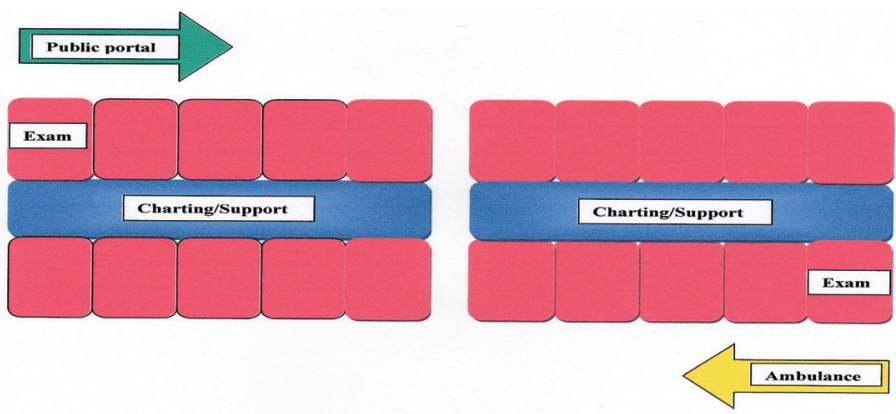

5. ábra "Linear/Inner Core” (magyarul: linearis/belső mag) vagy más néven „perimeter corridor" (magyarul: szélső folyosó) kialakítású sürgősségi osztály

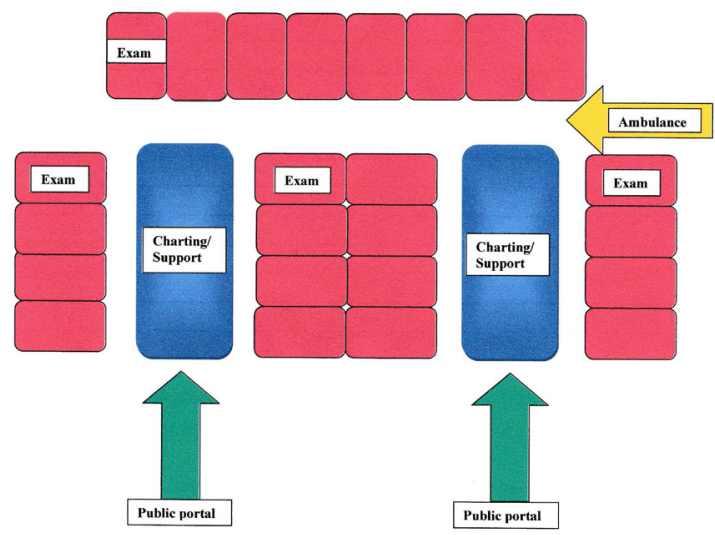

6. ábra „Pod” (magyarul: tok, hüvely) vagy más néven „mátrix” kialakitás 


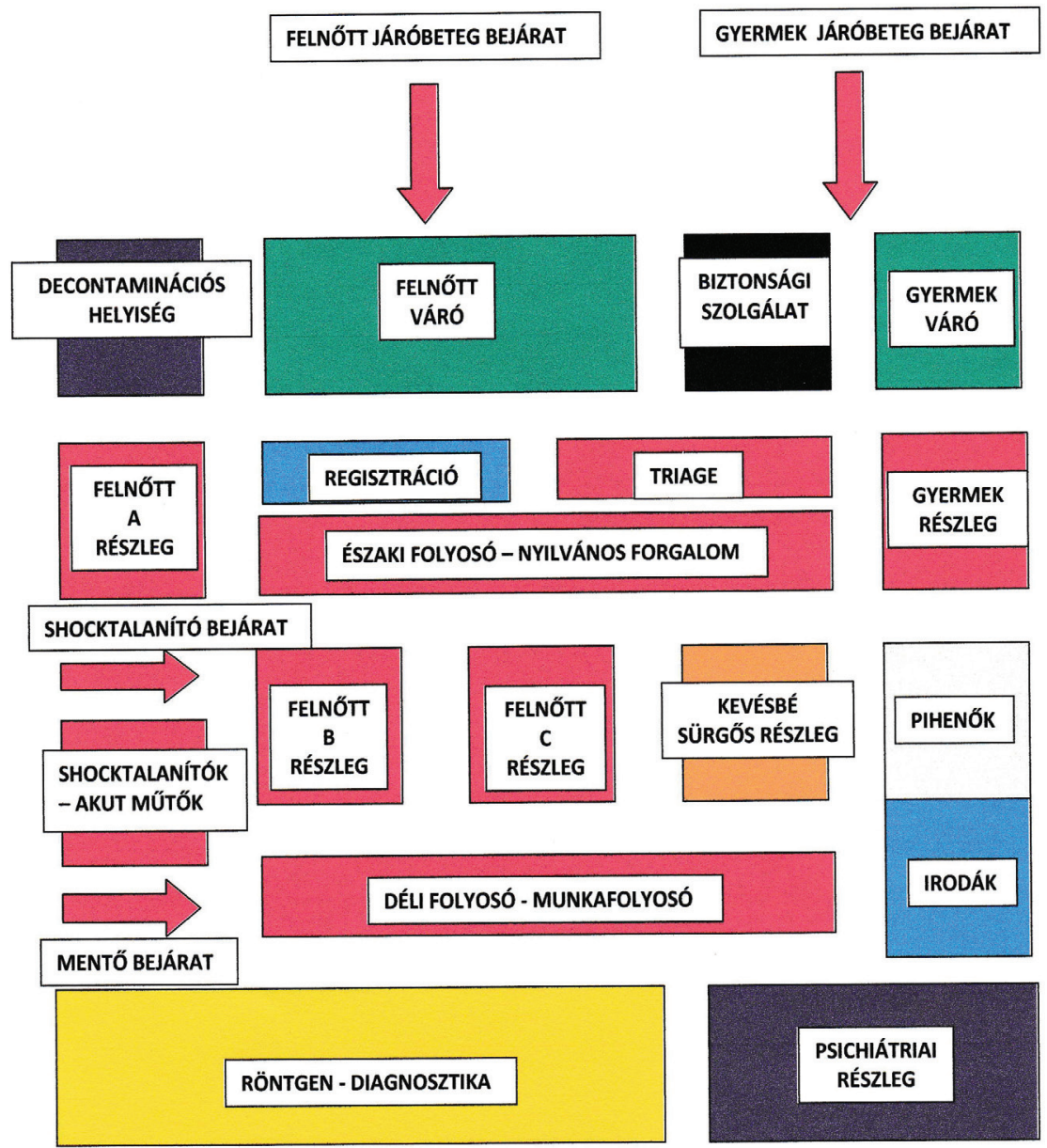

7. ábra Sürgősségi Osztály, Baystate Medical Center, Springfield, Massachusetts, USA, sematikus alaprajza

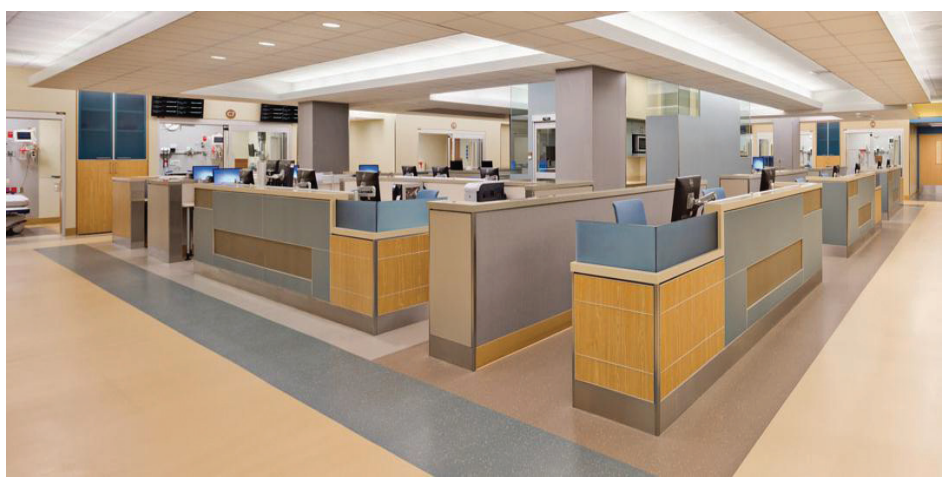

8. ábra A sürgősségi osztály egyik felnőtt részlegének központi nővérpultja, Baystate Medical Center, Springfield, Massachusetts, USA

A Baystate Medical Center, Emergency Department

valamennyi ábrájának forrása: http://mededboston.com/images/featured_photos/T11 Emergency Department Design.pdf 


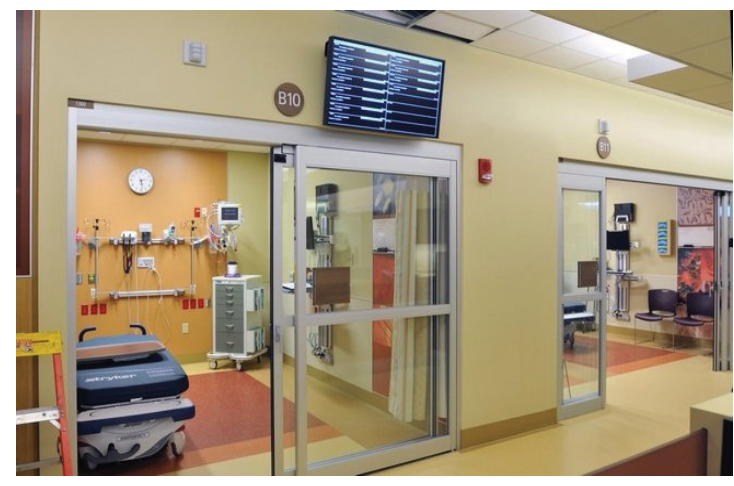

9. ábra Vizsgáló

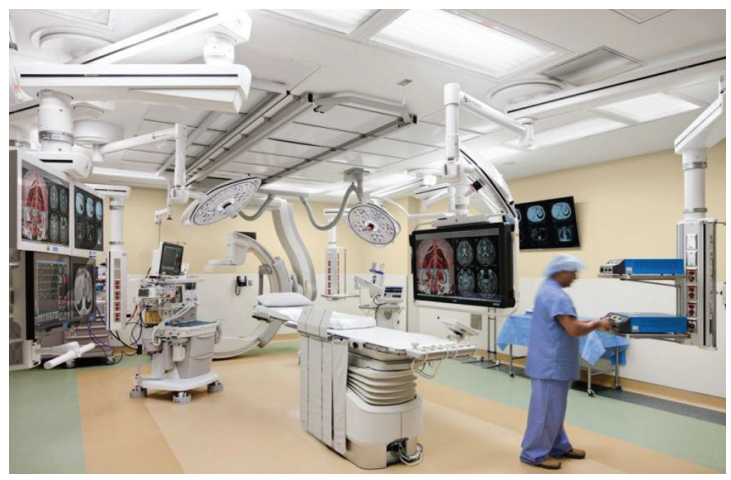

10. ábra A három shocktalanító egyike (Trauma room) teljes mútő felszereltséggel

\section{ELÖREMUTATÓ MAGYARORSZÁGI PÉLDÁK}

\section{Szeged}

Előremutató magyarországi példa a 2014 májusában átadott Szegedi Tudományegyetem Szent-Györgyi Albert Klinikai Központ Sürgősségi Betegellátó Osztálya, amely SBO1 minősítéssel rendelkezik. Az Új Klinika Sürgősségi Osztályára érkezik az összes traumatológiai, sebészeti, belgyógyászati, neurológiai és toxikológiai beteg. A sürgősségi osztályon belül öt munkafolyosót, és így öt zónát hoztak létre, mindegyiket külön színkóddal ellátva. Ezáltal különítik el a különböző súlyosságú betegcsoportokat. A sürgősségi osztály kialakítása az angolszász „linear layout” lineáris kialakítású alaprajzhoz hasonlít.

\section{Debrecen}

Debrecenben kialakított sürgősségi ellátó rendszerben a trauma ambulancia és a sürgősségi betegellátó osztály egymás mellett van. A sürgősségi betegellátó osztály SBO1 minősítéssel rendelkezik.

A bejáratánál egységes egykapus triage van, a Canadian Triage Acuity Scale ötfokozatú osztályozási rendszert alkalmazva. Az összes képalkotó diagnosztika a sürgősségi blokkban van, és gyorsan elérhető. A Kenézy Kórház jelenlegi Sürgősségi Betegellátó Osztálya alapvetően belgyógyászati sürgősséget lát el. $\mathrm{Az}$ általános sebészt, idegsebészt stb. konzíliumba hívják. A trauma aetiológiájú eseteket a baleseti ambulancia látja el.

A Kenézy Kórház sürgősségi ellátó rendszer alapelve leginkább az izraeli sürgősségi modellhez hasonlít. Izraelben a sürgősségi osztályoknak Sebészeti (Surgery) és Belgyógyászati (Internal Medicine) része van. Izraelben és más országokban is a sürgősségi osztályok sebészeti ellátásának legnagyobb forgalmát a trauma adja. 


\section{MEGBESZÉLÉS}

A német rendszerű jól szervezett baleseti ambulanciák, és az angolszász rendszerű egységes sürgősségi osztályok kialakítása hasonló, egyszerü alapelveken nyugszik.

Mindkét rendszerben külön járóbeteg bejárat, külön mentőbejárat, külön sokktalanító bejárat van, és az ellátás során is igyekeznek elkülöníteni ezen különböző súlyosságú betegcsoportokat. A váróban lévő és az ellátó részbe bekerült betegek, már nem keverednek össze. Fontos alapelv, hogy lehetőleg az ellátó személyzet mozogjon és minél kevesebbet a beteg. Ez az egyirányú betegutak programok lényege. Lényeges a bejárat mellett kialakított dekontaminációs helyiség, és a biztonsági szolgálat folyamatos jelenléte.

Építészmérnökök és sürgősségi ellátásban dolgozó orvosok szerint, nincs két egyforma sürgősségi ellátó hely a világon. Mindenhol a helyi igényeknek megfelelően kell kialakítani az infrastruktúrát. Bármilyen felújítás, bővítés vagy új építkezés előtt át kell tekinteni az elmúlt tíz év betegforgalmi adatait, a várható tendenciákat, és a tervezésbe be kell vonni az ott dolgozó orvosokat és nővéreket is, akik legjobban ismerik a helyi viszonyokat.
Egy sürgősségi osztály sohasem készül el teljesen, és épül fel véglegesen. Soha nincs kész. A lakosság számának, összetételének és igényeinek változása miatt 10-20 évente újra kell gondolni az ellátás rendszerét, és általában a felújítás mellett bővíteni kell a kapacitásokat, vagy akár teljesen új épületet kell felépíteni.

Mindemellett ismerni kell a német-francia és az angolszász sürgősségi mentés és ellátási filozófia és sürgősségi ellátó hely kialakítás alapelveit, és ezek előnyeit felhasználva, a helyi viszonyoknak megfelelő infrastruktúrát és betegutakat kell kialakítani.

Véleményünk szerint a magyarországi SBO1 minősítésű sürgősségi betegellátó osztályok kialakításánál mindenképpen törekedni kell arra, hogy vagy a sürgősségi osztályon belül, vagy közvetlenül mellette legyen a trauma ambulancia, mivel folyamatosan növekszik a betegforgalom, és az esetek fokozódó komplexicitása is ezt igényli.

Mindeközben Magyarországon a sürgősségi szakorvosok száma nem emelkedik a korábban elképzelt mértékben, képzésükben a sebészeti és baleseti sebészeti oktatás hiányos, ezen területeken kompetenciájuk is vitatott, ugyanakkor a sürgősségi megkeresések és esetek több mint felét még mindig a traumás sérültek teszik ki. 


\section{IRODALOM}

1. ACEP: Emergency Department Planning and Resource Guidelines, Policy Statement, Revised and approved by the American College of Emergency Physicians Board of Directors, Dallas, April 2014.

2. Al-Shaqsi S.: Models of International Emergency Medical Service (EMS) Systems. Oman Med. J. 2010. 25. (4): $320-323$.

3. Állami Számvevőszék: Jelentés a sürgösségi betegellátó rendszer kialakitására, fejlesztésére fordított pénzeszközök felhasználásának ellenörzéséröl. Budapest, 2009. augusztus

4. Boudreaux E. D., O'Hea E. L.: Patient satisfaction in the Emergency Department: a review of the literature and implications for practice. J. Emerg. Med. 2004. 26. (1): 13-26.

5. Dick W. F.: Anglo-American vs. Franco-German emergency medical services system. Prehosp. Disaster Med. 2003. 18. (1): 29-37.

6. Dózsa Cs., Belicza É., Berényi T., Burány B., Engelbrecht l., Mezőfi M., Pikó K., Szepesi A., Takács Z., Borcsek B.: A hazai sürgősségi ellátás fejlesztésének programja. Magyar Sürgősségi Orvostani Társaság, Budapest, 2006.

7. Huddy J.: Emergency Department design: A practical guide to planning for the future, American College of Emergency Physicians (ACEP), 2006.

8. Mader M., Clarke K.: Today's ED: Designing Efficient Emergency Departments in the 21st Century, Medical Construction and Design, May 13, 2014. http://mcdmag.com/2014/05/todays-er-designing-efficient-emergency-departments-in-the21st-century/

9. Mazzi A.: New strategies in ED design, Health Facilities Management, 01.07.2015. http://www.hfmmagazine.com/display/ HFMnewsarticle.dhtml?dcrPath=/templatedata/HF_Common/NewsArticle/data/HFM/Magazine/2015/Jan/designemergency-department-architecture

10. Nestor C.: The ideal Emergency Department. March 1, 2004. Health Care Design. http://www. healthcaredesignmagazine. com/article/ideal-emergency-department

11. Olsen J. C., Cutcliffe B., O'Brien B. C.: Emergency department design and patient perceptions of privacy and confidentiality. J. Emerg. Med. 2008. 35. (3): 317-320.

12. Rodak S.: Eight trends in emergency department design. November 08, 2012., Becker's Hospital Review. http://www. beckershospitalreview.com/capacity-management/8-trends-in-emergency-department-design.html

13. Schumacher J. G.: Emergency medicine and older adults: continuing challenges and opportunities. Am. J. Emerg. Med. 2005. 23. (4): 556-560.

14. Shah M. N.: The formation of the emergency medical services system. Am. J. Public Health. 2006. 96. (3): 414-423.

15. Stone C. K., Humphries R. L.: Current diagnosis and treatment emergency medicine. 7. ed. Lange, 2011.

16. Strauss R., Gillet J. B., Beniskev I., Polynikis A., Hlavackova D., Lippert F. K., Seer M., Silfvast T., Benedicte I., Lemke H., Efstathiou P., Engelbrecht l. et al.: Emergency Medical Services Systems in the European Union. World Health Organization Regional Office for Europe, Copenhagen, 2008.

17. Timmermanna A., Russoa S. G., Hollmann M. W.: Paramedic versus emergency physician emergency medical service: role of the anaesthesiologist and the European versus the Anglo-American concept. Curr. Opin. Anesthesiol. 2008. 21: 222-227.

18. Trzeciak S., Rivers E. P.: Emergency department overcrowding in the United States: an emerging threat to patient safety and public health. Emerg. Med. J. 2003. 20: 402-405.

19. Weiss S. J., Ernst A. A., Ong M., Jones R., Morrow D., Milch R., O'Neil K., Glass J. and others: Effect of a social services intervention among 911 repeat users. Am. J. Emerg. Med. 2005. 23. (4): 492-496.

20. Zilm F.: Designing for emergencies. Health facilities management. Nov.01.2010. http://www.hfmmagazine.com/ display/HFM-news-article.dhtml?dcrPath=/templatedata/HF_Common/NewsArticle/data/HFM/Magazine/2010/ Nov/1011HFM_FEA_AD

\section{Dr. Frendl István}

DE ÁOK Traumatológiai és Kézsebészeti Tanszék

4031 Debrecen Bartók út 2-26. 